\title{
The Iranian Uprisings and the Challenge of the New Media: Rethinking the Politics of Representation
}

\author{
Henry A. Giroux
}

The new communications technology and the diverse social networking sites associated with it are generally represented in the dominant media in terms that are utterly depoliticizing and privatizing, and reduced to personal tools and entertainment devices that allegedly enamour young people all over the world.[1] Little is said about either the prevalent technological and market driven rationalities that guides the dominant uses of the electronically based media or how the diverse screen cultures that enable it - such as Facebook, Twitter, and other social networking platforms - either enhance or limit matters of agency, ethics, knowledge, and social responsibility.[2] Herbert Marcuse's concern about how instrumental rationality has undermined technology's emancipatory possibilities, reducing it to a tool for domination are too often ignored, except by a few critical scholars whose work is generally missing from larger public debates about the new media.[3] For instance Zygmunt Bauman warns about how screen culture and its virtual networking sites undermine democratic notions of the social while promoting a culture of privatization, a culture more akin to the dictates of neoliberalism than democracy. He writes: "[w]e talk compulsively about networks and try obsessively to conjure them (or at least their phantoms) our of 'speed dating', personal ads and magic incantations of 'messaging' because we painfully miss the safety nets which the true networks of kinship, friends and brothers-in-fate used to provide matter-of-factly, with or without our efforts. Mobile-telephone directories stand for the missing community and are hoped to deputize for the missing intimacy; they are expected to carry a load of expectations they lack the strength to lift, let alone to hold."[4] While Bauman indeed captures the transformation of North American consumer culture through the new digital media, other sites have also emerged that defy, even as they are made possible by, neoliberal logic and technological domination. Perhaps most significantly, the democratic protests in Iran that alleged electoral fraud in the election of President Mahmoud Ahmadinejad on June 12, 2009 have rekindled questions about the relations between the new media and the terms on which politics operates, the new media's potential to revitalize the public sphere, and its construction of social practices and modes of communication that cannot be defined exclusively within the power relations of the nation state.

As the uprisings in Iran illustrate, the new electronic technologies and popular social networking sites they have produced have transformed both the landscape of media production and reception as well as the ability of state power to define the borders and boundaries of what constitutes the very nature of political engagement. Indeed, politics itself has been increasingly redefined by a screen culture and newly emergent public spaces of education and resistance embraced by students and other young people.[5] For example, nearly 75 percent of Iranians now own cell phones and are quite savvy in utilizing them. [6] Screen culture and its attendant electronic technologies have created a return to a politics in which many young people in Iran are not only forcefully asserting the power to act and express their criticisms and support of Mir Hussein Moussavi but also willing to risk their lives in the face of attacks by thugs and state sponsored vigilante groups. Texts and images calling for "Death to the dictator" circulate in a wild zone of representation on the Internet, YouTube, and among Facebook and Twitter users, giving rise to a chorus of dissent and collective resistance that places many young people in danger and at the forefront of a massive political uprising. Reports have emerged in the press and other media outlets about a number of protesters being attacked or killed by 
government forces, especially as the government launches an assault on the demonstrators in the aftermath of Iran's supreme leader Ayatollah Ali Khamenei insistence that there "would be 'bloodshed,' if street protests continued over the disputed presidential election."'[7] In the face of massive arrests by the police and threats of execution from some government officials, public protest continued to be visible in the world media-though, as Nazila Fathi reported in the New York Times on June 18, 2009, the Iranian government worked "on many fronts to shield the outside world's view of the unrest, banning coverage of the demonstrations, arresting journalists, threatening bloggers and trying to block Web sites like Facebook and Twitter, which have become vital outlets for information about the rising confrontation here.' $[8]$

It is impossible to comprehend the political nature of the existing protests in Iran (and recently in Moldova) without recognizing the centrality of the new visual media and new modes of social networking. Not only have these new mass and image-based media_camcorders, cellular camera-phones, satellite television, digital recorders, and the Internet, to name a few-enacted a structural transformation of everyday life by fusing sophisticated electronic technologies with a ubiquitous screen culture. They have revolutionized the relationship between the moment of an event and its public display by making events accessible almost instantly to a global audience. The Internet, You'Tube, Twitter, and Facebook have reconstituted, especially among young people, how social relationships are constructed and how communication is produced, mediated, and received. They have also ushered in a new regime of visual imagery in which screen culture creates spectacular events just as much as they record them. Under such circumstances, state power becomes more porous and less controlled and its instability becomes evident as the Iranian government points to the United States and Canada for producing "deviant news sites." As if such charges can compete with images uploaded on YouTube of a young man bleeding to death as a result of an assault by government forces, his white shirt stained with blood, and bystanders holding his hand while he died.[9] Or for that matter suppress images of militia members along with other identifying information about the police and other thugs attacking the protesters. The Internet and the new media outlets in this context provide new public sites of visibility for an unprecedented look into the workings of both state sponsored violence, massive unrest, and a politics of massive resistance that simply cannot be controlled by traditional forces of repression.

The pedagogical force of culture is now writ large within circuits of global transmission that defy the military power of the state while simultaneously provoking the state's reliance on physical force and military power to respond to the external threat and to control its own citizens. In Iran, the state sponsored war against democracy, with its requisite pedagogy of fear dominating every conceivable media outlet, creates the conditions for transforming a fundamentalist theocratic state into a more dangerous overtly militaristic authoritarian regime. Meanwhile, insurgents use digital video cameras to defy official power, cell phones to recruit members to battle occupying forces, and Twitter messages to challenge the doctrines of fear, militarism, and censorship. The endless flashing of screen culture not only confronts those in and outside of Iran with the reality of state sponsored violence and corruption but also with the spread of new social cartographies of power and resistance among young people as an emerging reality of contemporary politics in Iran. Text messaging, cell phone images, Facebook, Twitter, YouTube, and the Internet have given rise to a reservoir of political energy that posits a new relationship between the new media technologies, politics and public life-a glimpse of which was seen in the ways in which young people in the United States mobilized to get out the vote for Obama in the 2008 U.S. presidential election. These new media technologies and Web sites have proved a powerful force in resisting dominant channels of censorship and militarism. But they have done more in that they have allowed an emerging generation of young people and students in Iran to narrate their political views, convictions, and voices through a screen culture that opposes the one-dimensional cultural apparatuses of certainty while rewriting the space of politics through new social networking sites and public spheres.

A spectacular flood of images produced by a subversive interconnected web of technologies that opened up a cinematic politics of collective resistance and social justice now overrode Iran's official narratives of repression, totalitarianism, and orthodoxy-unleashing the wrath of a generation that hungers for a life in which matters of dignity, agency, and hope are aligned with democratic institutions that make them possible. Death and suffering are now inscribed in an order of politics and power that can no longer hide in the shadows, pretending that there are no cracks in its body politic, or suppressing the voices of a younger generation emboldened by their own courage and dreams of a more democratic future.

In this remarkable historical moment, a sea of courageous young people in Iran, are leading the way in instructing an older generation about a new form of politics in which mass and image-based media have become a distinctly powerful pedagogical force, reconfiguring the very nature of politics, cultural production, engagement, and resistance. Under such circumstances, this young generation of Iranian students, educators, artists, and citizens are 
developing a new set of theoretical tools and modes of collective resistance in which the educational force of the new media both records and challenges representations of state, police, and militia violence while becoming part of a broader struggle for democracy itself.

While forging a new conception of politics, education, and society, the courageous uprisings in Iran also try to understand how the new media and electronic technologies can be used less as entertainment than as a tool of insurgency and opposition to state power. State power no longer has a hold on information, at least not the way it did before the emergence of the new media with its ability to reconfigure public exchange and social relations while constituting a new sphere of politics. The new media technologies are being used in Iran in ways that redefine the very conditions that make politics possible. Public spaces emerge in which data and technologies are employed to bypass government censors. The public and the private inform each other as personal discontent is translated into broader social issues. Global publics of opposition emerge through electronic circuits of power offering up wider spheres of exchange, dialogue, and resistance-and a broader theoretical conception of the value of cultural politics. For example, protesters from all over the world are producing proxy servers, "making their own computers available to Iranians," and fuelling worldwide outrage and protests by uploading on YouTube live videos exposing the "brutality of the regime's crackdown." [10] Demonstrations of solidarity are emerging between the Iranian diaspora, students, and other protesters within Iran as information, technological resources, and skills are exchanged through the Internet, cell phones, and other technologies and sites. The alienation felt by many young people in an utterly repressive and fundamentalist society is exacerbated within a government- and media-produced culture of fear, suggesting that the terror they face at home and abroad cannot be fought without surrendering one's sense of agency and social justice to a militarized state. And yet, as the technology of the media expands so do the sites for critical education, resistance, and collective struggle.

The uprisings in Iran not only require a new conception of politics, education, and society; they also raise significant questions about the new media and its centrality to democracy. Image-based technologies have redefined the relationship between the ethical, political, and aesthetic. While "the proximity is perhaps discomforting to some, ... it is also the condition of any serious intervention" [11] into what it means to connect cultural politics to matters of political and social responsibility. The rise of the new media and the conditions that have produced it do not sound the death knell of democracy as some have argued, but demand that we "begin to rethink democracy from within these conditions." [12] These brave Iranian youth are providing the world with a lesson in how the rest of us might construct a cultural politics based on social relations that enable individuals and social groups to rethink the crucial nature of what it means to make power visible, exhibit civic courage, and assume a measure of social responsibility in a media-saturated global sphere. They are working out in real time what it means to address how these new media technologies might foster a democratic cultural politics that challenges religious fundamentalism, state censorship, militarism, and the cult of certainty. Such a collective project requires a politics that is in the process of being invented, one that has to be attentive to the new realities of power, global social movements, and the promise of a planetary democracy. Both the old and new media processes and the technologies of screen culture are inextricably implicated in not simply the crisis of information and communication, but the crisis of democracy itself. Whatever the outcome, the magnificent and brave uprising by the young people of Iran illustrates that they have legitimated once again a new register of both opposition and politics. What is at stake, in part, is a mode of resistance and educational practice that is redefining in the heat of the battle the ideologies and skills needed to critically understand the new visual and visualizing technologies not simply as new modes of communication, but as weapons in the struggle for expanding and deepening the ideals and possibilities of democratic public life and the supportive cultures vital to democracy's survival.

As these students and young people have demonstrated, it would be a mistake to simply align the new media exclusively with the forces of domination and commercialism as many critics do in the United Sates-with what Allen Feldman calls "total spectrum violence."[13] The Iranian uprising with its recognition of the image as a key force of social power makes clear that cultural politics is now constituted by a plurality of sites of resistance and social struggle, offering up new ways for young people to conceptualize how the media might be used to create alternative public spheres that enable them to claim their own voices and challenge the dominant forces of oppression. Theorists such as Thomas Keenan, Mark Poster, Douglas Kellner, and Jacques Derrida are right in suggesting that the new electronic technologies and media publics "remove restrictions on the horizon of possible communications" [14] and, in doing so, suggest new possibilities for engaging the new media as a democratic force both for critique and for positive intervention and change. The ongoing struggle in Iran, if examined closely, provides some resources for rethinking how the political is connected to particular understandings of the social; how 
distinctive modes of address are used to marshal specific and often dangerous narratives, memories, and histories; and how certain pedagogical practices are employed in mobilizing a range of affective investments around images of trauma, suffering, and collective struggles. The images and messages coming out of Iran both demonstrate the courage of this generation of young people and others while also signifying new possibilities for redefining a global democratic politics. What the dictatorship in Iran is witnessing is not simply generational discontent or the power of networking and communication sites such as Twitter, Facebook, and YouTube but a much more dangerous lesson in which democracy implies an experience in which power is shared, dialogue is connected to involvement in the public sphere, hope means imagining the unimaginable, and collective action portends the outlines of a new understanding of power, freedom, and democracy. Unfortunately, hope manifested in this important struggle against a rigid theocratic government found little support among the Obama administration. Hope in this case was sacrificed to the logic of political centrism and expediency-which translates into tread carefully and make sure you offend no one. Obama's audacity of hope seems to have little relevance when it comes to those youth who constitute the global other pushing hard against fundamentalism in the interest of democratization.

As the crushing force of the state bears down on the students and other protestors in Iran, pushing their struggles out of the streets and into the shadows of power, it is crucial to grasp both the strengths and the limitations of screen culture in this ongoing political conflict. Those whose voices are removed from the narratives of official power have found new ways to counter such narratives, criticize them, and offer counter-narratives in their place. The new media and its social networks point to distinct modes of representation and a more capacious politics for correcting what Nick Couldry calls "current injustices of representation.”[15] Yet, they are only a precondition for the more crucial task of both organizing people and diverse publics around political struggles and goals and building long term organizations and social movements that have the power to challenge dominant regimes through a diverse number of political channels and actions. The new media may be highly novel in its ability to bring mass numbers of people into the streets, but as Angela Davis points out, long term organizing is not synonymous with mobilizing demonstrations. As she puts it, "It is difficult to encourage people to think about protracted struggles, protracted movements that require very careful organizing interventions that don't always depend on our capacity to mobilize demonstrations. It seems to be that mobilization had displaced organization, so that in the contemporary moment, when we think about organizing movements, we think about bringing masses of people into the streets."'[16] Let's hope that in the aftermath of the massive demonstrations in Tehran, we can rethink not only how the new media technologies of screen culture and electronically mediated social networks can refigure existing modes of communication, but also rewrite a democratic politics in which social movements can emerge that challenge those anti-democratic tendencies in Iran and other countries around the world. The new technologies with their instant modes of communication have a purpose as we have seen not only in Iran, but also among various forms of opposition that have emerged in China, Moldova, and Egypt. But what is crucial now is the fostering of relationships to technology that are predicated not only on instant, widely circulated, and uncensored modes of communication but also on creating the conditions for the development of critical literacies, modes of agency, critical thinking, and other aspects of civic engagement and education that are the precondition for any lasting form of democratic governance and social relations.

\section{Endnotes}

1. A typical example is Noam Cohen, "Twitter on the Barricades: Six Lessons Learned," New York Times (June 21, 2009), p. wk 4. While acknowledging the role Twitter is playing in the Iranian uprisings, Cohen is content to analyze Twitter solely as a communication tool suggesting, for instance, we cannot believe everything that is posed on Twitter.

2. Two interesting articles on the relationship between the Internet and democracy, see Evgeny Morozov, “Texting Towards Utopia," Boston Review (March April 2009). Online: http://bostonreview.net/BR34.2/ morozov.php and Linda Jean Kenix, "The Internet as a Tool for Democracy?" First Monday 13:7 (July 2008). Online: http://www.uic.edu/htbin/cgiwrap/ bin/ojs/index.php/fm/article/view/2124/1984. For some important work on the new media, see: Nick dyer-Witheford, Cyber-Marx: Cycles and Circuits of Struggle in High-Technology Capitalism (Chicago: University Of Illinois Press, 1999); Manuel Castells, The Internet Galaxy (New York: Oxford University Press, 2001); Nick Couldry, Media Rituals (New York: Routledge, 2003); Mark Poster, Information Please: Culture and Politics in the Age of Digital Machines 
(Durham: Duke University Press, 2006); Megan Boler, ed. Digital Media and Democracy (Cambridge: MIT Press, 2008).

3. Herbert Marcuse, One Dimensional Man (Boston: Beacon Press, 1964).

4. Zygmunt Bauman, Wasted Lives, (London: Polity Press, 2004), p. 130.

5. I take up the issue of screen culture and the challenge of the new media in Henry A. Giroux, Beyond the Spectacle of Terrorism: Global Uncertainty and the Challenge of the New Media (Boulder: Paradigm Publishers, 2006).

6. I want to thank Tony Kashani for these figures and his help with some questions raised by this article.

7. Robert F. Worth, "Security Forces and Protesters Clash in Tehran," New York Times (June 21, 2009), p. 1.

8. Nazila Fathi, "Protesters Defy Iranian Efforts to Cloak Unrest," New York Times (June 18, 2009), p. A1.

9. Brian Stelter and Brad Stone, "Stark Images of the Turmoil in Iran, Uploaded to the World on the Internet," New York Times (June 18, 2009), p. A14.
10. Ibid., Stelter and Stone, "Stark Images of the Turmoil in Iran," p. A14.

11. Thomas Keenan, "Mobilizing Shame," South Atlantic Quarterly 103, no. 2/3 (2004), p. 447. Keenan explores the relationship between ethics and responsibility in even greater detail in his Fables of Responsibility (Stanford: Stanford University Press, 1997).

12. Jacques Derrida cited in Michael Peters, "The Promise of Politics and Pedagogy in Derrida," Review of Education/Pedagogy/Cultural Studies (in press).

13. Allen Feldman, "On the Actuarial Gaze: From 9/11 to Abu Ghraib," Cultural Studies 19, no. 2 (March 2005), p. 212.

14 Jürgen Habermas, Theory of Communicative Action, Vol. 2. Lifeworld and System: A Critique of Functionalist Reason, trans. Thomas McCarthy (Cambridge, UK: Polity Press, 1987), p. 390.

15. Nick Couldry, "Media and the Problem of Voice," unpublished paper (2009).

16. Angela Davis, Abolition Democracy: Beyond Empire, Prisons, and Torture (New York: Seven Stories Press, 2005), pp. 128-129. 
